\title{
Selenium enriched vegetables as biofortification alternative for alleviating micronutrient malnutrition
}

\author{
El-Ramady, H. R., ${ }^{1,2}$ Alla, N. A., ${ }^{1,3}$ Fári, M. ${ }^{1}$ \& Domokos-Szabolcsy, É. ${ }^{1}$ \\ ${ }^{I}$ Agricultural Botany, Plant Physiology and Biotechnology Dept., Debrecen University \\ ${ }^{2}$ Soil and Water Sciences Dept., Faculty of Agriculture, Kafrelsheikh University, Egypt \\ ${ }^{3}$ Plant Biotechnology Dept., Genetic Engineering Division, National Research Center, Giza, Egypt
}

\begin{abstract}
Summary: There is a very difficult equation for malnutrition and over-consumption. That means malnutrition even of vitamins and/or minerals ( $\mathrm{Ca}, \mathrm{Cu}, \mathrm{Fe}, \mathrm{I}, \mathrm{Mg}$, Se and $\mathrm{Zn}$, vitamin A) affects more than two billion people worldwide, largely due to low concentrations or poor bioavailability of the nutrients in the diet. In some developed countries in contrast, over-consumption, particularly of over-refined cerealbased foods, has contributed to the development of an epidemic of metabolic diseases. So, producing nutritious and safe foods sufficiently and sustainably is important target at the same time challenge of modern agriculture. In the past, great efforts have focused only on increasing crop yields, but enhancing the concentrations of mineral micronutrients has become an urgent task. The main daily food source is the staple crops specially in developing countries of the world, i.e., wheat, rice, cassava, beans, sweet potato or maize. These kind of plants are often deficient in some of mineral elements. Thus, the increasing of bioavailable concentration of micronutrients in edible crop tissues (via biofortification) has become a promising strategy in modern agriculture, providing more nutritious foods, to more people, with the use of fewer lands. Biofortification of these trace elements can be achieved application with agronomic process such as soil or foliar fertilization or crop breeding even conventional technic and/or genetic engineering. This review highlight progress to date and identify challenges faced in delivering biofortified vegetable crops as well as the agronomic approaches and tools to improve crop yield and micronutrient content of food crops.
\end{abstract}

Keywords: biofortification, vegetable crops, selenium, food safety, malnutrition, over-consumption

\section{Introduction}

Nowadays, micronutrient deficiency has become a limiting factor for crop productivity in many agricultural lands worldwide. Furthermore, many food systems in developing countries can not provide sufficient micronutrient content to meet the demands of their citizens, especially low-income families (Bouis and Welch, 2011). Around half of the world population suffers from malnutrition of such macro-, and microelements as calcium, copper, iron, iodine, magnesium, selenium and zinc (Zhao and McGrath, 2009). Furthermore, most of the major staple crops of the world, i.e., wheat, rice, cassava, beans, sweet potato or maize are often deficient in some of these mineral elements. Thus, the increasing of bioavailable concentration of micronutrients in edible crop tissues (biofortification) has become a promising strategy in modern agriculture, allowing the access of more nutritious foods, to more people, with the use of fewer resources (Carvalho and Vasconcelos 2013).

Two main strategies are known enhancing micronutrient status of crops: one of them genetically improved food crops which are richer in bioavailable micronutrients, either through conventional breeding or genetic modification (Johns and Eyzaguirre 2007). The process of breeding nutrients into food crops, provides a sustainable, long-term strategy
(Saltzman et al. 2013). Micronutrient-efficient genotypes could ensure a number of benefits such as reductions in the use of fertilizers, improvements in vitality, and resistance against abiotic and abiotic stresses. At the same time using bioavailable micronutrient-dense staple crop cultivars can also be used to improve the micronutrient nutritional status of human (Khoshgoftarmanesh et al. 2010). The agronomical biofortification includes several solutions such as soil and foliar fertilization, crop systems, application of organic amendments.

On a global level, particularly in developing countries, it is above all deficiencies in iron, zinc and iodine that are recognized to have a negative impact on public health (Horton et al. 2008). Also deficiencies in calcium and selenium are considered to represent public health problems, albeit less significant ones (Black et al. 2008), and in sub-populations or at regional levels also deficiencies in magnesium and copper may represent more common health problems as reviewed by Stein 2010 .

Vegetables are very important source of antioxidants and nutraceutical compounds for the human diet. The most part of these compounds act against free radicals/reactive oxygen species (ROS) in plants as well as in humans (Steinbrenner and Sies 2009). ROS include free radicals such as the superoxide anion, hydroxyl, lipid radicals, oxidizing non- 
radical species, hydrogen peroxide, peroxynitrite and singlet oxygen.

In general, selenium (Se) has been demonstrated, as a component of different enzymes such as gluthathione peroxidase and thioredoxinreductase, to play an important role in the antioxidant defense system of human and mammals cells (Birringer et al. 2002; Ellis and Salt, 2003). However plants don't need Se to keep the normal metabolism but they can transform inorganic Se to organic selenoaminoacids and their derivatives. It has been clinically demonstrated that selenoaminoacid derivatives have anticarcinogenic proprieties. The optimum concentration of Se uptake is limited to a very narrow concentration range and outside of it deficiency or toxicity may occur so easily (Ferrarese et al., 2012).

Considering the essentiality of Se for human health biorfortication of staple and/or vegetable crops with $\mathrm{Se}$ offer a good solution decreasing the deficieny. However using agromnomical strategies such as Se-fertilizers must be performed under very strict conditions, since an overaccumulation in the edible parts might be toxic for consumers (Makela et al. 1995). Se is not essential for Higher plants although evidence of its beneficial effects on plant growth and stress tolerance is increasing (Hartikainen, 2005).

Therefore, this review highlights progress to date and identifies challenges faced in delivering biofortified vegtable crops special regard selenium as essential microelement for human.

\section{Biofortification: why?}

Humans require at least 44 known nutrients in adequate amounts, whereas at least 20 dietary minerals and trace elements are essential for the proper functioning of the human body (Bouis and Welch, 2011). Consequently, if they are not ingested in adequate amounts (or are poorly bioavailable), there will be negative impacts on the health of those who consume too little of these nutrients. It is well known that millions of people worldwide consume insufficient nutirents or for adequate health. Besides dietary supplements, and mineral enriched processed food, dietary mutrient (like as $\mathrm{Se}, \mathrm{Zn}, \mathrm{Fe}$ etc.) intake can potentially be increased through crop biofortification (Broadley et al., 2009).

Biofortification is a process of increasing the natural content of bioavailable nutrients such as selenium in crop plants (Hirschi 2008). Biofortification relies on the plant's biosynthetic (vitamins) or physiological (minerals) capacity to produce or accumulate the desired nutrients (Mayer et al. 2008). This term can also be used to refer to the actual process whereby crops load higher levels of minerals and vitamins in their organs.

Plants are at the beginning of every food chain. Therefore, improving the uptake of minerals from the soil and enhancing their translocation and bioavailability in the edible parts, can provide benefits for animal and human nutrition. From this aspect two main challenges are ahead: firstly developing crop plants that have an increased content of essential minerals in the edible parts at the same time exclude toxic elements that exhibit similar chemical properties; secondly avoid sequestration of nutrients in the inedible parts of the plant (Palmgren et al. 2008). Biofortification requires increasing public investment in agricultural research and infrastructure. The nutrients enhancing efforts in developing countries should focus on vegetatively propagated crop species or improving quality of cereals, vegetables, as well as fodders. Using agricultural biodiversity to reinforce dietary diversity can help locate biofortification within the larger context of sustainable food-based approaches (Johns and Eyzaguirre 2007).

\section{Strategies for biofortification of food crops}

Plants are extremely versatile biochemical factories, capable of synthesizing a nearly full complement of essential dietary micronutrients; however, these are unevenly distributed among different plant parts. For instance, iron content of a rice leaf is high (100-200 $\mathrm{mg} \mathrm{kg}^{-1}$ ) but very low in the polished rice grain $\left(3 \mathrm{mg} \mathrm{kg}^{-1}\right)$. Similarly, provitamin A carotenoids are present in rice leaves only. Unfortunately, poor people specially in developing countries consume low amount of vegetable. Predominantly food source of these social layer are the starchy staples such as wheat, rice, maize, or cassava, which do not provide the biochemical diversity needed for a healthy life.

Biofortification is a process with target to increase the bioavailable nutrient/mineral content of crop plants. Biofortified crops can provide advantages both for human and plants (Winkler, 2011).

In general, three complementary strategies can be employed to increase mineral concentrations in edible crops (White and Broadley 2009). One of the most important strategy is "agronomical" biofortification, employs the use of fertilizers containing the mineral elements lacking in human diets. A common limitation for agronomical biofortification is the generally low phytoavailability of mineral micronutrients in the soil. Thus, the agronomic efforts have been directed toward the application of mineral fertilizers and the improvement of the solubilization and mobilization of mineral elements in the soil Principally $\mathrm{Zn}, \mathrm{Cu}, \mathrm{Fe}, \mathrm{I}, \mathrm{Se}$, $\mathrm{Mg}$, and $\mathrm{Ca}$ are the main micro-, and macroelements which are applied as soil inorganic fertilizer, amendments (such as composts and manures). The high $\mathrm{pH}$ of soil inhibits the minerals uptake, therefore acidifying fertilizers (such as urea, ammonium nitrate, ammonium sulphate, ammonium phosphates, or elemental S) are useful to rectify soil alkalinity or lime. Appropriate crop rotations, intercropping, or the introduction of beneficial soil microorganisms to increase the phytoavailability of mineral elements could also be important tools of agronomical biofortification (White and Greenwood 2012). Several authors have reviewed appropriate methods, infrastructural requirements, and practical benefits for food production, economic sustainability, and human health of 
agronomic biofortification of edible crops (Cakmak 2009). Inter alia Se addition to soil fertilizerled to increase dietary Se intakes in Finland and New Zealand (Hartikainen 2005; White and Broadley 2005). The iodinization of irrigation water also increased effectively dietary intakes of I in Xinjiang, China (Dai et al. 2004; Lyons et al. 2004). Last but least fertilizers containing $\mathrm{Zn}$ as agronomical biofortification increased the crop production at the same time dietary $\mathrm{Zn}$ intakes, and human health in Anatolia, Turkey (Cakmak 2009).

The agronomical biofortification by soil fertilizers are relatively simple with fast results but the success of it depends on several factors such as physical and chemical characterisation of soil, mineral mobility and soil microbial activities (Hirschi 2009). Therefore this method cannot be seen as an universal approach for enhancing the micronutrient levels in edible crop tissues. Several times mineral elements (such as $\mathrm{Fe}$ or $\mathrm{Zn}$ ) become rapidly unavailable to roots, the use of foliar fertilizers, rather than soil fertilizers, is recommended (Fageria et al. 2011).

The second and third strategies are connected, because both of them are based on breeding. The difference is in the method what are used: conventional breeding or genetic engineering. The aim of "genetic" biofortification is improving plant genotypes with increased abilities to acquire mineral elements from the environment, for a higher capacity to accumulate micronutrients in the edible plant tissues and to increase their bioavailability to humans (White et al. 2012; Carvalho and Vasconcelos 2013).

Of course the biofortification strategies are exist not only separately however application of mineral fertilizers can be combined with breeding crop varieties providing higher efficiency in mineral accumulation of vegetable and staple crops reach the final aim which is alleviating mineral malnutrition of humans (White and Broadley 2009).

It is likely that farmers even in developed or developing countries may adopt new genotypes that acquire mineral elements more efficiently, particularly if biofortified produce demands a premium price along with crops can be grown on soils with low phytoavailability of mineral elements with reduced fertilizer inputs, better germination, seedling vigour and higher resistance to abiotic and biotic stresses (Cakmak 2008; Graham et al. 2007).

\section{Biofortification and post-harvest processes}

Besides the biofortification strategies harvesting crops at the optimal state of maturity is well known criterion for optimizing nutritional quality of plants. In addition, postharvest processing of plant tissues has been used for a long time to enhance nutritional quality via either the release of nutrients that may otherwise be bound by plant tissues or by elimination or destruction of toxins and anti-nutrients. The post-harvest processes include cooking (thermal processing), fermentation, germination, milling, and soaking of edible plant parts (Sands et al. 2009). For example, thermal processing is well-known to enhance the nutritional quality of grain legume proteins by inactivating trypsin and haemagglutinins (Tharanathan and Mahadevamma 2003). Heating can also destroy anti-nutrients such as goitrogens, thiaminases and phytates (Hotz and Gibson 2007).

However, postharvest processing is not always advantageous for nutritional quality. Salt, heat, alkaline or acidic conditions, light, and copper cooking utensils can decrease concentrations of vitamins (A, C, B1 and B2 and of folate and carotenoides). Nevertheless, post harvest processing is an important strategy for balancing the physiological constraints of plants for their health and vigorous growth with the nutritional needs of humans (Sands et al., 2009).

\section{Biofortification of vegetable crops with $\mathrm{Se}$}

It could be noticed that, the importance and using of Se for biofortifying crops, is less comparing with other elements (from $\mathrm{Ca}$ to $\mathrm{Zn}$ ). Being that $\mathrm{Se}$ is a microelement it needs in micro molar concentration for all animals and humans however above this concentration it can be reached easily the toxic level (White and Broadley 2005). The recommended dietary allowance in the USA is $55 \mu \mathrm{g} \mathrm{Se} \mathrm{d^{-1 }}$ and the reference nutrient intake in the UK is $60-75 \mu \mathrm{g} \mathrm{Se}$ $\mathrm{d}^{-1}$ (White and Broadley 2005). Se deficiency in humans is associated with cardiovascular disorders, hypothyroidism, a weakened immune system, male infertility, and increased incidence of various cancers. It is estimated that about $15 \%$ of the world's population are suffered from different levels of Se deficiency, which is a consequence of consuming crops grown on Se poor soils (White et al. 2007). Selenium fertilizers are generally applied to pastures and forages at a rate of 5-10 g Se ha ${ }^{-1}$ year $^{-1}$. The most frequent applied form is water-soluble selenate salt (such as $\mathrm{Na}_{2} \mathrm{SeO}_{4}$ or $\mathrm{K}_{2} \mathrm{SeO}_{4}$ ) provides an immediate source for Se uptake by plants. However these days the interest is going to turn towards to the selenite or a less soluble selenate salt such as $\mathrm{BaSeO}_{4}$ providing longer-lasting Se availability. Se concentrations in food crops can also be increased through Se fertilization (Broadley et al. 2006). The selenium agronomical strategy has been pioneered in Finland, where the addition of Se to fertilizer formulations has been mandatory since 1984 and currently soil fertilizers containing $10 \mathrm{mg} \mathrm{Se} \mathrm{kg}^{-1}$ (White et al. 2007).

Vegetable crops are important part of the daily diet. Therefore biofortifying vegetables can contribute alleviating the selenium deficiency. Beside soil fertilizer several other agronomical attempts are known enhancing Se content of different vegetables in open or closed system as collected the Table 1.

There are difference in sensitivity of chemical forms and amount of selenium between vegetable species. The Se sensitivity of species is derived from alterations in Se metabolism. According to Brown and Shrift (1981), Seaccumulating plants could tolerate large amounts of $\mathrm{Se}$ 
due to a mechanism responsible for excluding Se from incorporation into proteins. None of the vegetable plants seems to possess this mechanism in spite of the fact that three of these belong to the Brassicaceae family (radish, cauliflower and turnip) and two to the Alliaceae family (onion and garlic). Both families possess several secondary accumulator members which can grow on soil with low to medium Se content and can accumulate up to $1000 \mathrm{mg} \$ \mathrm{~kg}^{-1}$ Se (Brown and Shrift 1982). The Se toxicity were observed due to interference with sulphur metabolism. Selenium can substitute for $\mathrm{S}$ leading to the formation of Se analogues of $\mathrm{S}$ organic compounds in plants. Similarity of Se-aminoacids to their S-analogues of cysteine and methionine can built into functional protein disrupt them (Anderson and Scarf 1983). The nuclear diameter of Se is higher than S so incorporation of Se into proteins can result in the alteration of protein structure, inactivation of proteins, which eventually lead to metabolic disorders of plants Dhillon and Dhillon (2009).

Vegetable sprouts are some-day-old baby plants which have increasingly interest in these days beacuse of their nutritional values. Enhancing of sprouting seeds with selenium is special form of vegetables biofortification. The sprouting process could be achieved in closed system using different germinating devices. The micro-farms are considered an promising tools for biofortifying vegetable crops as shown in Fig. 1.

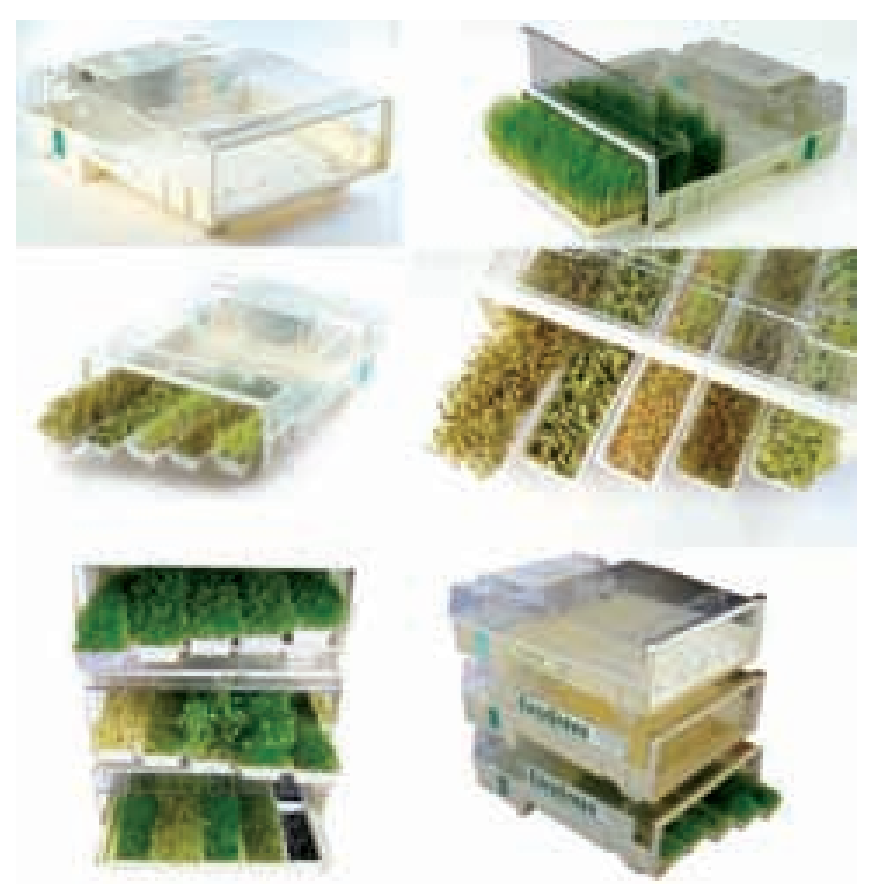

Fig. 1: Micro-farm, as a model for plant nutrition and soil fertility research. These photos represent the using of micro-farm for sprouts production as well as for different plant nutrition research. These photos with kind permission from Eric Viard (http://www.easygreeneurope.com/10.3.2013)

It could be used micro-farm automatically to grow a large variety of seeds, baby greens, beans, shoots, and wheatgrass, under any climate conditions, at any time of the year, with or without soil. Some micro-farm is supplied with one large tray for wheatgrass and five standard cartridges for sprouts. Some models are stackable, so that it could be purchased one first to suit the present needs and add more modules as the desires change. The micro-farm has a built-in water reservoir so that you can locate the machine in any convenient place, not necessarily near a water source. Micro-farm includes built-in mist irrigator, timer, 5 standard sized cartridges, and drainage tube. It could be used this micro-farm system to follow plant nutrition sprouter production and plant nutrition research (Fig. 1). It could be also modified the micro-farm system to evaluate different plant nutrition studies. The micro-farm sprouter could be used a patented technology of misting water and air on the surface of the seeds (El-Ramady et al. 2013b). In this system continuous Se fortification can be achieved as foliar application. At the same Se solution can change to water before harvesting removing the Se residue which has stuck to the sprouts surface. The advantage of foliar application compared with soil fertilization with Se for bio-fortification is that losses caused by soil adsorption, chemical or microbiologically mediated conversions or losses are not likely to occur (Table 1). Furthermore, the direct foliar uptake ensures higher efficiency of assimilation by the plant (Kápolna et al., 2009; Kápolna et al., 2012).

\section{Conclusion}

This paper has described the biofortification of vegetable crops with Se and the different tools for agronomic biofortification. It has also highlighted different strageties of biofortification. Function of minerals and elements in humans and higher plants, which use in biofortified crops were highlighted. It has noted that the problems of mineral deficiencies and toxicities must be addressed to maximize crop production in both intensive and extensive agricultural systems. The chemical constraints to crop production on acid, saline, alkaline and sodic soils can be addressed through agronomy or the development of tolerant genotypes. In intensive agricultural systems, it is likely that inorganic fertilizers will continue to be required to maintain yields. To reduce the entry of toxic elements into the human food chain, strict quality requirements for inorganic and organic fertilizers might be enforced, agronomic strategies could be used to reduce the phytoavailability of these elements, and crop genotypes can be developed that do not accumulate toxic concentrations of mineral elements in their edible tissues. On the other hand, to increase the dietary delivery of mineral elements essential to human wellbeing, agronomic strategies to increase the phytoavailability of these elements combined with the cultivation of crops that acquire and accumulate greater concentrations of these elements in their edible tissues can be pursued where there is sufficiency of these elements present in the soil to support mineral dense crops. However, where these essential elements are not present in the soil, the application of fertilizers containing these elements is required to increase their amounts in human diets, if diets remain unchanged. Thus, interdisciplinary research 
Table 1: Total concentration and forms of Se in leaves of cultivated crop plants exposed to Se under different experimental conditions as a result of fortification with different Se forms

\begin{tabular}{|c|c|c|c|}
\hline $\begin{array}{c}\text { Experimentation } \\
\text { medium/ vegetable } \\
\text { crop }\end{array}$ & $\begin{array}{c}\text { Se addition (rate, } \\
\left.\mathrm{mg}^{-1}\right)^{*} \text { and period } \\
\text { of experiment }\end{array}$ & $\begin{array}{c}\text { Total } \\
\text { Se } \\
\left(\mu g g^{-1}\right)\end{array}$ & References \\
\hline \multicolumn{4}{|c|}{ Nutrient solution medium } \\
\hline \multirow{2}{*}{$\begin{array}{l}\text { Lupine } \\
\text { (Lupinus albus) }\end{array}$} & $\mathrm{Na}_{2} \mathrm{SeO}_{4}(1) 14$ days & 631 & \multirow{4}{*}{$\begin{array}{l}\text { Ximénez- } \\
\text { Embún et al. } \\
(2004)\end{array}$} \\
\hline & $\mathrm{Na}_{2} \mathrm{SeO}_{3}(1) 41$ days & 50 & \\
\hline \multirow{2}{*}{$\begin{array}{l}\text { Sunflower } \\
\text { (Helianthus annuus) }\end{array}$} & $\mathrm{Na}_{2} \mathrm{SeO}_{4}(1) 14$ days & 73 & \\
\hline & $\mathrm{Na}_{2} \mathrm{SeO}_{3}(1) 14$ days & 12 & \\
\hline \multirow{3}{*}{$\begin{array}{l}\text { Cichory } \\
\text { (Cichorium intybus) }\end{array}$} & $\mathrm{Na}_{2} \mathrm{SeO}_{4}(7) 5$ days & 88 & \multirow{3}{*}{$\begin{array}{l}\text { Mazej et al. } \\
(2006)\end{array}$} \\
\hline & $\mathrm{Na}_{2} \mathrm{SeO}_{4}(7) 10$ days & 131 & \\
\hline & $\mathrm{Na}_{2} \mathrm{SeO}_{4}(7) 41$ days & 480 & \\
\hline \multicolumn{4}{|c|}{ Pot experiments (green house) } \\
\hline $\begin{array}{l}\text { Lettuce (L. sativa) } \\
\text { young (YS) and } \\
\text { senescing seedlings } \\
(\mathrm{SS})\end{array}$ & $\begin{array}{l}\mathrm{H}_{2} \mathrm{SeO}_{4}(1) 7 \text { weeks } \\
\text { (YS) } \\
\mathrm{H}_{2} \mathrm{SeO}_{4} \text { (1) } 14 \text { weeks } \\
(\mathrm{SS})\end{array}$ & $\begin{array}{r}270 \\
41\end{array}$ & $\begin{array}{l}\text { Xue et al. } \\
(2001)\end{array}$ \\
\hline $\begin{array}{l}\text { Potato (S. tuberosum) } \\
\text { tubers }\end{array}$ & $\begin{array}{l}\mathrm{Na}_{2} \mathrm{SeO}_{4}(0.3) 15 \\
\text { weeks }\end{array}$ & 7.4 & $\begin{array}{l}\text { Turakainen et } \\
\text { al. (2004) }\end{array}$ \\
\hline $\begin{array}{l}\text { Potato (S. tuberosum) } \\
\text { edible part }\end{array}$ & $\mathrm{Na}_{2} \mathrm{SeO}_{4}(5) 45$ days & 33 & \multirow[t]{6}{*}{$\begin{array}{l}\text { Dhillon and } \\
\text { Dhillon (2009) }\end{array}$} \\
\hline $\begin{array}{l}\text { Carrot (Daucus } \\
\text { carota), Id }\end{array}$ & $\mathrm{Na}_{2} \mathrm{SeO}_{4}(5) 45$ days & 35 & \\
\hline $\begin{array}{l}\text { Radish (Raphanus } \\
\text { sativus L.), Id }\end{array}$ & $\mathrm{Na}_{2} \mathrm{SeO}_{4}(5) 45$ days & 45 & \\
\hline $\begin{array}{l}\text { Garlic (Allium } \\
\text { sativum), Id }\end{array}$ & $\mathrm{Na}_{2} \mathrm{SeO}_{4}(5) 45$ days & 53 & \\
\hline $\begin{array}{l}\text { Turnip (Brassica } \\
\text { rapa), Id }\end{array}$ & $\mathrm{Na}_{2} \mathrm{SeO}_{4}(5) 45$ days & 65 & \\
\hline $\begin{array}{l}\text { Spinach (Spinacia } \\
\text { oleracea }), \mathrm{Id}\end{array}$ & $\mathrm{Na}_{2} \mathrm{SeO}_{4}(5) 45$ days & 93 & \\
\hline \multirow[t]{2}{*}{$\begin{array}{l}\text { Onion (Allium cepa cv. } \\
\text { Sturon) }\end{array}$} & $\begin{array}{l}\mathrm{Na}_{2} \mathrm{SeO}_{3}(50) 17 \\
\text { weeks, leaf }^{\dagger}\end{array}$ & 6.3 & \multirow[t]{4}{*}{$\begin{array}{l}\text { Kápolna et al. } \\
(2012)\end{array}$} \\
\hline & $\begin{array}{l}\mathrm{Na}_{2} \mathrm{SeO}_{3}(50) 17 \\
\text { weeks, bulb }\end{array}$ & 6.8 & \\
\hline \multirow[t]{2}{*}{$\begin{array}{l}\text { Carrot (D. carota } \mathrm{cv} . \\
\text { Bolero) }\end{array}$} & $\begin{array}{l}\mathrm{Na}_{2} \mathrm{SeO}_{3}(50) 17 \\
\text { weeks, root }\end{array}$ & 2.8 & \\
\hline & $\begin{array}{l}\mathrm{Na}_{2} \mathrm{SeO}_{3}(50) 17 \\
\text { weeks, leaf }\end{array}$ & 25.0 & \\
\hline \multirow[t]{3}{*}{$\begin{array}{l}\text { Onion (Allium nutans } \\
\text { L.) }\end{array}$} & $\begin{array}{l}\mathrm{Na}_{2} \mathrm{SeO}_{3}(2.3) 17 \\
\text { weeks, leaf }\end{array}$ & 0.41 & \multirow[t]{3}{*}{$\begin{array}{l}\text { Golubkina et al } \\
(2012)\end{array}$} \\
\hline & $\begin{array}{l}\mathrm{Se}^{0}(2.3) 17 \text { weeks, } \\
\text { leaf }\end{array}$ & 0.72 & \\
\hline & $\begin{array}{l}\mathrm{Na}_{2} \mathrm{SeO}_{4}(2.3) 17 \\
\text { weeks, leaf }\end{array}$ & 1.08 & \\
\hline \multicolumn{4}{|l|}{ Field experiments } \\
\hline \multirow[t]{2}{*}{ Turnip (Brassica rapa) } & $\mathrm{Na}_{2} \mathrm{SeO}_{4}\left(20 \mathrm{~g} \mathrm{ha}^{-1}\right)$ & 1.05 & \multirow{4}{*}{$\begin{array}{l}\text { Seppänen et al. } \\
(2010)\end{array}$} \\
\hline & $\mathrm{Na}_{2} \mathrm{SeO}_{3}\left(20 \mathrm{~g} \mathrm{ha}^{-1}\right)$ & 0.85 & \\
\hline \multirow[t]{2}{*}{ Oilseed rape $(B$. napus $)$} & $\mathrm{Na}_{2} \mathrm{SeO}_{4}\left(20 \mathrm{~g} \mathrm{ha}^{-1}\right)$ & 1.59 & \\
\hline & $\mathrm{Na}_{2} \mathrm{SeO}_{3}\left(20 \mathrm{~g} \mathrm{ha}^{-1}\right)$ & 1.55 & \\
\hline \multicolumn{4}{|l|}{ Hydroponics medium } \\
\hline \multirow[t]{2}{*}{ Onion (Allium cepa) } & $\mathrm{Na}_{2} \mathrm{SeO}_{3}(5) 8$ days & 154 & \multirow{2}{*}{$\begin{array}{l}\text { Wróbel et al. } \\
(2004)\end{array}$} \\
\hline & $\mathrm{Na}_{2} \mathrm{SeO}_{4}(5) 8$ days & 601 & \\
\hline $\begin{array}{l}\text { Green onion }(A . \\
\text { fistulosum) }\end{array}$ & $\begin{array}{l}\mathrm{Na}_{2} \mathrm{SeO}_{3}(15) 14 \\
\text { days }{ }^{\dagger \dagger}\end{array}$ & 30 & $\begin{array}{l}\text { Shah et al. } \\
(2004)\end{array}$ \\
\hline $\begin{array}{l}\text { Green onion (A.f. va. } \\
\text { Tetenyi r.) }\end{array}$ & $\mathrm{Na}_{2} \mathrm{SeO}_{4}(10) 28$ days & 199 & \multirow{2}{*}{$\begin{array}{l}\text { Domokos- } \\
\text { Szabolcsy et al. } \\
(2006)\end{array}$} \\
\hline $\begin{array}{l}\text { Green onion (A.f. va. } \\
\text { Makoi br.) }\end{array}$ & $\mathrm{Na}_{2} \mathrm{SeO}_{4}(10) 28$ days & 348 & \\
\hline
\end{tabular}

\begin{tabular}{|c|c|c|c|}
\hline $\begin{array}{c}\text { Experimentation } \\
\text { medium/ vegetable } \\
\text { crop }\end{array}$ & \begin{tabular}{|c|} 
Se addition (rate, \\
$\mathrm{mg} \mathrm{L}^{-1}$ ) ${ }^{*}$ and period \\
of experiment
\end{tabular} & $\begin{array}{c}\text { Total } \\
\text { Se } \\
\left(\mu g^{-1}\right)\end{array}$ & References \\
\hline \multicolumn{4}{|c|}{ Absorbent cotton medium } \\
\hline Onion (Allium cepa) & $\begin{array}{l}\mathrm{Na}_{2} \mathrm{SeO}_{3}(10) 7 \\
\text { days }\end{array}$ & 17.8 & \multirow[t]{9}{*}{$\begin{array}{l}\text { Sugihara et al. } \\
(2004)\end{array}$} \\
\hline $\begin{array}{l}\text { Eggplant (Solanum } \\
\text { melongena) }\end{array}$ & $\begin{array}{l}\mathrm{Na}_{2} \mathrm{SeO}_{3}(10) 15 \\
\text { days }\end{array}$ & 22.0 & \\
\hline $\begin{array}{l}\text { Spinach (Spinacia } \\
\text { oleracea) }\end{array}$ & $\begin{array}{l}\mathrm{Na}_{2} \mathrm{SeO}_{3}(10) 8 \\
\text { days }\end{array}$ & 25.6 & \\
\hline $\begin{array}{l}\text { Lettuce (Lactuca } \\
\text { sativa) }\end{array}$ & $\begin{array}{l}\mathrm{Na}_{2} \mathrm{SeO}_{3}(10) 7 \\
\text { days }\end{array}$ & 27.3 & \\
\hline Carrot (Daucus carota) & $\begin{array}{l}\mathrm{Na}_{2} \mathrm{SeO}_{3}(10) 8 \\
\text { days }\end{array}$ & 29.0 & \\
\hline $\begin{array}{l}\text { Broccoli (Brassica } \\
\text { oleracea) }\end{array}$ & $\begin{array}{l}\mathrm{Na}_{2} \mathrm{SeO}_{3}(10) 8 \\
\text { days }\end{array}$ & 32.1 & \\
\hline $\begin{array}{l}\text { Chinese cabbage ( } B . \\
\text { campestris) }\end{array}$ & $\begin{array}{l}\mathrm{Na}_{2} \mathrm{SeO}_{3}(10) 7 \\
\text { days }\end{array}$ & 36.5 & \\
\hline Turnip (Brassica rapa) & $\begin{array}{l}\mathrm{Na}_{2} \mathrm{SeO}_{3}(10) 8 \\
\text { days }\end{array}$ & 37.7 & \\
\hline $\begin{array}{l}\text { Parsley (Petroselinum } \\
\text { crispum) }\end{array}$ & $\begin{array}{l}\mathrm{Na}_{2} \mathrm{SeO}_{3}(10) 15 \\
\text { days } * *\end{array}$ & 46.3 & \\
\hline \multicolumn{4}{|c|}{ Growth chamber medium } \\
\hline \multirow[t]{2}{*}{$\begin{array}{l}\text { Lettuce (L. sativa L. cv } \\
\text { Philipus) }\end{array}$} & $\begin{array}{l}\mathrm{Na}_{2} \mathrm{SeO}_{3}(20) 66 \\
\text { days, leaf }\end{array}$ & 40.0 & \multirow[t]{2}{*}{$\begin{array}{l}\text { Ríos et al. } \\
(2008)\end{array}$} \\
\hline & $\begin{array}{l}\mathrm{Na}_{2} \mathrm{SeO}_{4}(20) 66 \\
\text { days, leaf }\end{array}$ & 45.0 & \\
\hline \multirow[t]{4}{*}{$\begin{array}{l}\text { Carrot (Daucus carota) } \\
\text { foliar ap. }\end{array}$} & $\begin{array}{l}\mathrm{Na}_{2} \mathrm{SeO}_{3}(10) 13 \\
\text { weeks, root }\end{array}$ & 0.4 & \multirow[t]{4}{*}{$\begin{array}{l}\text { Kapolna et al. } \\
(2009)\end{array}$} \\
\hline & $\begin{array}{l}\mathrm{Na}_{2} \mathrm{SeO}_{3}(10) 13 \\
\text { weeks, leaf } \\
\end{array}$ & 5.1 & \\
\hline & $\begin{array}{l}\mathrm{Na}_{2} \mathrm{SeO}_{4}(10) 13 \\
\text { weeks, root } \\
\end{array}$ & 0.5 & \\
\hline & $\begin{array}{l}\mathrm{Na}_{2} \mathrm{SeO}_{4}(10) 13 \\
\text { weeks, leaf }\end{array}$ & 5.7 & \\
\hline \multicolumn{4}{|c|}{ Closed fortification system } \\
\hline $\begin{array}{l}\text { Onion (A. cepa cv } \\
\text { Makói bronz) }\end{array}$ & $\mathrm{Na}_{2} \mathrm{SeO}_{4}(10) 21$ days & 93 & \multirow{2}{*}{$\begin{array}{l}\text { Domokos- } \\
\text { Szabolcsy et al. } \\
(2011)\end{array}$} \\
\hline $\begin{array}{l}\text { Onion (A. cepa cv } \\
\text { Makói lila) }\end{array}$ & $\mathrm{Na}_{2} \mathrm{SeO}_{4}(10) 21$ days & 100 & \\
\hline \multicolumn{4}{|l|}{ In vitro culture medium } \\
\hline \multirow[t]{2}{*}{$\begin{array}{l}\text { Radish (Raphanus } \\
\text { sativus L.) }\end{array}$} & $\begin{array}{l}\mathrm{Na}_{2} \mathrm{SeO}_{4}(10) 7 \text { days, } \\
\text { roots }\end{array}$ & 420 & \multirow{2}{*}{\begin{tabular}{|l} 
Domokos- \\
Szabolcsy et al \\
$(2005)$
\end{tabular}} \\
\hline & \begin{tabular}{|l|}
$\mathrm{Na}_{2} \mathrm{SeO}_{4}(10) 7$ days, \\
shoots
\end{tabular} & 75 & \\
\hline \multicolumn{4}{|l|}{ Micro-farm condition } \\
\hline \multirow{3}{*}{$\begin{array}{l}\text { Radish (R. sativus) } \\
\text { whole plant }\end{array}$} & $\mathrm{Na}_{2} \mathrm{SeO}_{4}(2) 10$ days & 69.2 & \multirow{3}{*}{$\begin{array}{l}\text { El-Ramady et } \\
\text { al. }(2013 a)\end{array}$} \\
\hline & $\mathrm{Na}_{2} \mathrm{SeO}_{4}(5) 10$ days & 211.0 & \\
\hline & $\mathrm{Na}_{2} \mathrm{SeO}_{4}(10) 10$ days & 303.6 & \\
\hline
\end{tabular}

* dry weight and $* *$ fresh weight (whole plant)

$\dagger$ Total Se concentration denotes sum of naturally occurring and isotopically enriched concentration, ${ }^{77} \mathrm{Se}(\mathrm{IV})$

${ }^{\dagger}$ Growing media are cell packs, which containing $3-5$ seeds and with four cells each of dimensions $(13 \mathrm{~cm} \times 13 \mathrm{~cm} \times 10 \mathrm{~cm})$ were employed. Each cell contained mixture of sphagnum, peat moss, perlite, vermiculite, dolomite and calicitic lime stone.

$¥$ Absorbent cotton (ca. $20 \mathrm{~g}$ ) was spread over the base of a synthetic resin container $(25 \mathrm{~cm} \times 35 \mathrm{~cm} \times 14 \mathrm{~cm})$ 
in plant mineral nutrition, soil science, agronomy, and crop breeding is required for future food security to improve soil quality, optimize fertilizer applications for sustainable crop production, and develop strategies for the biofortification of edible crops with essential mineral elements.

Growing sprouts from vegetable seeds is a special part of horticulture in closed system. Sprouting can achieved in different germinating devices from the simpliest germination bowl to the complex germination equipments are broad the scale. The micro-farms are considered a promising tool for germination. At the same time these germination systems allow using different target solutions instead of water enhancing the nutrient content (such as selenium) of sprouts.

Considering the human, economical and sociological gravity of the micronutrient deficiency special regard in developing countries the importance biofortification strategy/ strategies application are increasing even in open or closed system.

\section{Acknowledgments}

This research was supported by the European Union and the State of Hungary, co-financed by the European Social Fund in the framework of TÁMOP-4.2.4.A/ 2-11/1-2012-0001 'National Excellence Program'.

\section{References}

Anderson, J. W. and A. R. Scarf (1983). Selenium and plant metabolism. [In: Robb D A, PierpointWS, eds. Metals and Micronutrient: Uptake and Utilization by Plants.] New York: Academic Press, 241-275.

Birringer, M., S. Pilawa and L. Flohe (2002). Trends in selenium biochemistry. Natural Product Reports. 19: 693-718.

Black, R. E., L. A. Allen, Z. A. Bhutta, L. E. Caulfield, M. de Onis, M. Ezzati, C. Mathers and J. Rivera (2008). Maternal and child undernutrition: global and regional exposures and health consequences. Lancet 371:243-260 Also available via http://dx.doi. org/10.1016/S0140-6736(07)61690-0.

Bouis, H. E. and R. M. Welch (2011). Biofortifi cation-a sustainable agricultural strategy for reducing micronutrient malnutrition in the global south. Crop Sci. 50:S-20-S-32. doi: 10.2135/cropsci2009.09.0531.

Broadley, M. R.; J. P. Hammond, G. J. King, H. C. Bowen, R. M. Hayden, W. P. Spracklen, S. Lochlainn, P. J. White (2009). Biofortifying Brassica with calcium $(\mathrm{Ca})$ and magnesium $(\mathrm{Mg})$. Proceedings of the $16^{\text {th }}$ International Plant Nutrition Colloquium, Paper 1256.

Brown, T. A. and A. Shrift (1981). Exclusion of selenium from protein of selenium-tolerant Astragalus species. Plant Physiology, 67: 1051-1053

Brown, T. A. and A. Shrift (1982). Selenium: toxicity and tolerance in higher plants, Biol. Revs. 57: 59-84.

Cakmak, I. (2008). Enrichment of cereal grains with zinc: agronomic or genetic biofortification? Plant and Soil, 302 (1-2): 1-17.
Cakmak, I. (2009). Enrichment of fertilizers with zinc: an excellent investment for humanity and crop production in India. Journal of Trace Elements in Medicine and Biology, 23 (4): 281-289.

Carvalho, S. M. P. and M. W. Vasconcelos (2013). Producing more with less: Strategies and novel technologies for plant-based food biofortification. Food Research International, http://dx.doi. org/10.1016/j.foodres.2012.12.021.

Dai, J.-L., Y.-G. Zhu, M. Zhang and M.-Z. Huang (2004). Selecting iodine-enriched vegetables and the residual effect of iodate application to soil. Biological Trace Element Research, 101: 265-276.

Dhillon, K. S. and S. K. Dhillon (2009). Accumulation and distribution of selenium in some vegetable crops grown in selenateSe treated clay loam soil. Front. Agric. China, 3 (4): 366-373.

Domokos-Szabolcsy, É., H. Imre, P. József, K. Béla, V. Zsuzsanna and F. Miklós (2005). Impact of sodium-selenate on the growth of radish (Raphanus sativus L.) seedlings in vitro. International Journal of Horticultural Science, 11. (2): 113-117.

Domokos-Szabolcsy, É., J. Prokisch, A. Sztrik, A. Barnócki and M. Fári (2011). Variation in selenium tolerance among two cultivars in closed fortification system. International Journal of Horticultural Science, 17. (1-2): 75-77

Domokos-Szabolcsy, É., J. Prokisch, B. Kovacs, S. Marosi, I. J. Holb and M. Fari. (2006). Enhancing the selenium content of green onion made from bulb in hydroponic culture. International Symposium on Trace Elements in the Food Chain, Budapest, 2006. Procs. Eds.: Szilágyi M., Szentmihályi K. Working Committee on Trace Elements of the Hungarian Academy of Sciences (HAS) and Institute of Materials and Environmental Chemistry of the HAS, Budapest

Ellis, D. R. and D. E. Salt (2003). Plants, selenium and human health. Current Opinion In Plant Biology. 6: 273-279.

El-Ramady, H. R., T. A. Alshaal, S. A. Shehata, É. DomokosSzabolcsy, N. Elhawat, J. Prokisch M. Fári and L. Marton (2013b). Soil science, plant nutrition and micro-farms. [In: E. Lichtfouse (ed.), Sustainable Agriculture Reviews.] Vol. 14, Springer Science + Business Media B.V.

El-Ramady, H. R., T. Alshaal, É. Domokos-Szabolcsy, T. Shalaby, Y. Bayoumi, N. Elhawat, A. Sztrik, J. Prokisch and M. Fári (2013a). Selenium and its role in higher plants. [In: E. Lichtfouse (ed.), Environmental Chemistry for a Sustainable World.] Vol. 6, Springer Science + Business Media B.V.

Fageria, N. K., V. C. Baligar and C. A. Jones (2011). Growth and Mineral Nutrition of Field Crops. CRC Press, Boca Raton, Fla, USA, $3^{\text {rd }}$ edition.

Ferrarese, M., M. M. Sourestani, E. Quttrini, M. Schiavi, A. Ferrante (2012). Biofortification of spinach plants applying selenium in the nutrient solution of floating system. Vegetable Crops Research Bulletin. 76: 127-136.

Golubkina, N. A., G. E. Folmanis and I. G. Tananaev (2012). Comparative evaluation of selenium accumulation by Allium Species after foliar application of selenium nanoparticles, sodium selenite and sodium selenate. Doklady Biological Sciences, 444: 176-179.

Graham, R. D., R. M. Welch, D. A. Saunders, I. O. Monasterio, H. E. Bouis, M. Bonierbale, S. de Haan, G. Burgos, G. Thiele, R. Liria, C. A. Meisner, S. E. Beebe, M. J. Potts, M. Kadian, P. R. Hobbs, R. K. Gupta and S. Twomlow (2007). Nutritious Subsistence Food Systems. Advances in Agronomy, 92: 1-74. 
Hartikainen, H. (2005). Biogeochemistry of selenium and its impact on food chain quality and human health. J Trace Elem Med Biol. 18: 309-318.

Hirschi, K. (2008). Nutritional improvements in plants: time to bite on biofortified foods. Trends Plant Sci. 13: 459 - 463.

Hirschi, K. D. (2009). Nutrient biofortification of food crops. Annual Review of Nutrition, 29: 401-421.

Horton, S., H. Alderman and J. A. Rivera (2008). Hunger and malnutrition. Challenge paper 2008. Copenhagen Consensus, Frederiksberg Available via http://www.copenhagenconsensus. com/Default.aspx?ID=1149. Accessed 28/2/2009.

Hotz, C. and R. S. Gibson (2007). Traditional food-processing and preparation practices to enhance the bioavailability of micronutrients in plant-based diets. J Nutr. 137:1097-1100.

Johns, R. and P. B. Eyzaguirre (2007). Biofortification, biodiversity and diet: A search for complementary applications against poverty and malnutrition. Food Policy. 32: 1-24.

Kápolna, E., K. H. Laursen, S. Husted, E. H. Larsen (2012). Biofortification and isotopic labelling of Se metabolites in onions and carrots following foliar application of Se and ${ }^{77} \mathrm{Se}$. Food Chemistry. 133: 650-657.

Kápolna, E., P. R. Hillestrřm, K. H. Laursen, S. Husted and E. H. Larsen (2009). Effect of foliar application of selenium on its uptake and speciation in carrot. Food Chemistry. 115: 13571363.

Khoshgoftarmanesh, A. H., R. Schulin, R. L. Chaney, B. Daneshbakhsh and M. Afyuni (2010). Micronutrient-efficient genotypes for crop yield and nutritional quality in sustainable agriculture. A review. Agron. Sustain. Dev. 30: 83-107.

Lyons, G. H., J. C. R. Stangoulis and R. D. Graham (2004). Exploiting micronutrient interaction to optimize biofortification programs: the case for inclusion of selenium and iodine in the HarvestPlus program. Nutrition Reviews, 62 (6): 247-252.

Makela, A. L., W. C. Wang, M. Hamalainen, V. Nanto, P. Laihonen and H. Kotilainen (1995). Environmental effects of nationwide selenium fertilization in Finland. Biological Trace Element Research. 36: 151-157.

Mayer, J. E., W. H Pfeiffer and P. Beyer (2008). Biofortified crops to alleviate micronutrient malnutrition. Curr. Opin. Plant Biol. 11: 1-5.

Mazej, D, Falnoga I, Veber M, Stibilj V (2006). Determination of selenium species in plant leaves by HPLC-UV-HG-AFS. Talanta 68: 558-568.

Palmgren, M. G., S. Clemens, L. E. Williams, U. Kraemer, S. Borg, J. K. Schjørring and D. Sanders (2008). Zinc biofortification of cereals: problems and solutions. Trends in Plant Science. 13 (9): 464-473.

Ríos, J. J., B. Blasco, L. M. Cervilla Marı, M. Rubio-Wilhelmi, J. M. Ruiz and Luis Romero (2008). Regulation of sulphur assimilation in lettuce plants in the presence of selenium. Plant Growth Regul. 56: 43-51.

Saltzman, A., E. Birol, H. E. Bouis, E. Boy, F. F. De Moura, Y. Islam and W. H. Pfeiffer (2013). Biofortification: Progress toward a more nourishing future. Global Food Security. 2: 9-17.

Sands, D. C., C. E. Morris, E. A. Dratz and A. Pilgeram (2009). Elevating optimal human nutrition to a central goal of plant breeding and production of plant-based foods. Plant Sci. 117 (5): 377-389.

Seppänen, M. M., J. Kontturi, I. L. Heras, Y. Madrid, C. Cámara and H. Hartikainen (2010). Agronomic biofortification of
Brassica with selenium-enrichment of SeMet and its identification in Brassica seeds and meal. Plant Soil: 337: 273-283.

Shah, M., S. S. Kannamkumarath, J. C. A. Wuilloud, R. G. Wuillouda and J. A. Caruso (2004). Identification and characterization of selenium species in enriched green onion (Allium fistulosum) by HPLC-ICP-MS and ESI-ITMS. The Royal Society of Chemistry At. Spectrom., 1 9: 381 - 386.

Stein, A. J. (2010). Global impacts of human mineral malnutrition. Plant and Soil, 335 (1): 133-154.

Steinbrenner, H. and H. Sies (2009). Protection against reactive oxygen species by selenoproteins. Biochimica et Biophysica Acta. 1790: 1478-1485.

Sugihara, S., M. Kondo, Y. Chihara, M. Yuji, H. Hattori, M. Yoshida (2004). Preparation of Selenium-enriched Sprouts and Identification of Their Selenium Species by High-performance Liquid Chromatography-Inductively Coupled Plasma Mass Spectrometry. Biosci. Biotechnol. Biochem. 68: 193 - 199.

Tharanathan, R. N. and S. Mahadevamma (2003). Grain legumes - a boon to human nutrition. Trends Food Sci Tech. 14: 507-518.

Turakainen, M., H. Hartikainen and M. Sepänen (2004). Effect of selenium treatments on potato (Solanum tuberosum L.) growth and concentration of soluble sugars and starch. Journal of Agricultural and Food Chemistry, 52: 5378-5382.

White, P. J. and D. J. Greenwood (2012). Properties and management of cationic elements for crop growth. [In: Russell's Soil Conditions and Plant Growth, P. J. Gregory and S. Nortcliff,] Eds.,Wiley-Blackwell, Oxford, UK, $12^{\text {th }}$ edition.

White, P. J. and M. R. Broadley (2005). Biofortifying crops with essential mineral elements. Trends in Plant Science, 10 (12): 586-593.

White, P. J. and M. R. Broadley (2009). Biofortification of crops with seven mineral elements often lacking in human diets-iron, zinc, copper, calcium, magnesium, selenium and iodine. New Phytologist, 182 (1): 49-84.

White, P. J., M. R. Broadley and P. J. Gregory (2012). Managing the nutrition of plants and people. Applied and Environmental Soil Science,

White, P. J., M. R. Broadley, H. C. Bowen, and S. E. Johnson (2007). Selenium and its relationship with sulfur. [In: M.J. Hawkesford and L. J. De Kok (eds.) Sulfur in Plants - an Ecological Perspective.] Springer, pp: 225-252.

Winkler, J. T. (2011). Biofortification: improving the nutritional quality of staple crops. [In: C. Pasternak (Ed.), Access Not Excess] (pp. 100-112). Cambs: Smith-Gordon.

Wróbel, K., K. Z. Wróbel, S. S. Kannamkumarath, J. A. Caruso, I. A. Wysocka, E. Bulska, J. Swiatek and M. Wierzbicka (2004). HPLC-ICP-MS speciation of selenium in enriched onion leaves-a potential dietary source of Se-methylselenocysteine. Food Chemistry. 86: 617-623.

Ximénez-Embún, P., I. Alonso, Y. Madrid-Albarran, C. Camara (2004). Establishment of selenium uptake and species distribution in lupine, indian mustard and sunflower plants. J. Agric. Food Chem. 52: 832 .

Xue, T., H. Hartikainen and V. Piironen (2001). Antioxidative and growth-promoting effect of selenium in senescing lettuce. Plant Soil, 27: 55-61.

Zhao, F.-J. and S. P. McGrath (2009). Biofortification and phytoremediation. Current Opinion Plant Biology, 12: 373-380. 